\title{
MODEL PENURUNAN TINGGI MUKA AIR TANAH SETELAH KEJADIAN HUJAN DI LOKASI SISTEM PERINGATAN DINI LONGSOR DI KAMPUNG JATIRADIO, DESA CILILIN, KECAMATAN CILILIN, KABUPATEN BANDUNG BARAT
}

\section{GROUND WATER TABLE DECREASING MODEL AFTER RAIN EVENTS IN LANDSLIDE EARLY WARNING SYSTEM LOCATION IN JATIRADIO KAMPONG OF CILILIN VILLAGE, CILILIN DISTRICT, WEST BANDUNG REGENCY, WEST JAVA PROVINCE}

\author{
Prihartanto', Puspa Khaerani ${ }^{2}$, Akhmad Fakhrus Shomim², Syakira Trisnafiah ${ }^{2}$ \\ ${ }^{1}$ Perekayasa Utama pada Pusat Teknologi Reduksi Risiko Bencana - Badan Pengkajian dan \\ Penerapan Teknologi, Jl. M. H. Thamrin No. 8, Jakarta 10340, telepon: (021) 75791378 \\ email: prihartanto@bppt.go.id \\ ${ }^{2}$ Staff pada Pusat Teknologi Reduksi Risiko Bencana - Badan Pengkajian dan Penerapan \\ Teknologi, J. M. H. Thamrin No. 8, Jakarta 10340 \\ email: puspa.khaerani@bppt.go.id, achmad.fakhrus@bppt.go.id, syakira.trisnafiah@bppt.go.id
}

\begin{abstract}
Landslide events that have occurred in Jatiradio, Cililin Village, Cililin District, West Bandung Regency triggered the installation of a Landslide Early Warning System (LEWS). The equipment transmits data such as rainfall and ground water level for every hour which is detected from rain gauge sensors and pressure transducers. The relationship between rainfall and ground water level is important to understand in order to know the fluctuation patterns that trigger landslides. Therefore, mathematical model of the decline in groundwater level every time after the rainfall in Jatiradio, Cililin Village, Cililin District, West Bandung Regency during the 2019 rainy season was made. Thus, it can be seen, the relationship between rainfall patterns and water level fluctuations in certain rainfall periods is shown. The method used in producing the model is a regression model using spreedsheet software. Regression equations and coefficients of determination were obtained to analyze the relationship of ground water level to rainfall. The results of mathematical modeling between ground level I (February 23-24, 2019) and II (February 24-25, 2019) are linear to rainfall,.except the decline of groundwater level III which occurred on February 25-28, 2019 shows exponential relationship, meaning a rapid decline in groundwater level. The regression model equation obtained for the decline of each groundwater level is $y=-36.022 x+2339.2$ with $R^{2}=0.9631 ; y=-49.346 x+3111.2$ with $R^{2}=0.9988 ; y=2783.6 e^{-0.017 x}$ with $R^{2}=0.9903$.
\end{abstract}

Keywords: model, landslide, landslide early warning system, preparedness

\begin{abstract}
ABSTRAK
Kejadian bencana longsor yang pernah terjadi di Kampung Jatiradio, Desa Cililin, Kecamatan Cililin, Kabupaten Bandung Barat mendorong dipasangnya alat Landslide Early Warning System (LEWS). Alat tersebut mengirimkan data seperti curah hujan dan tinggi muka air tanah setiap satu jam yang dideteksi dari sensor penakar hujan dan pressure transducer. Hubungan antara curah hujan dan tinggi muka air tanah penting untuk diketahui agar dapat diketahui pola fluktuasi yang memicu longsor. Maka dari itu dibuat suatu model matematik untuk melihat penurunan tinggi muka air tanah setiap kali setelah kejadian hujan di Kampung Jatiradio, Desa Cililin, Kecamatan Cililin, Kabupaten Bandung Barat pada saat musim hujan 2019. Model penurunan tinggi muka air tersebut dapat dihubungkan dengan pola fluktuasi curah hujan yang terjadi dengan demikian dapat diketahui hubungan antara pola curah hujan dan pola fluktuasi tinggi muka air pada periode hujan tertentu. Metode yang digunakan dalam menghasilkan model tersebut yaitu model regresi dengan menggunakan perangkat lunak spreedsheet. Persamaan regresi dan koefisien determinasi didapatkan untuk menganalisis hubungan tinggi muka air tanah terhadap curah hujan. Hasil pemodelan matematika menghasilkan hubungan penurunan tinggi
\end{abstract}


muka air tanah I (23 - 24 Februari 2019) dan II (24-25 Februari 2019) yang linear terhadap curah hujan, kecuali penurunan tinggi muka air tanah III yang terjadi pada tanggal 25-28 Februari 2019 yang menunjukkan hubungan eksponensial, artinya terjadi penurunan tinggi muka air tanah yang cepat. Persamaan model regresi yang didapatkan untuk masing-masing penurunan yaitu $y=-$ $36,022 x+2339,2$ dengan $\mathrm{R}^{2}=0,9631 ; y=-49,346 x+3111,2$ dengan $\mathrm{R}^{2}=0,9988$; dan $y=$ 2783.6e $e^{-0.017 x}$ dengan $R^{2}=0,9903$.

Kata kunci: model, longsor, sistem peringatan dini longsor, kesiapsiagaan

\section{PENDAHULUAN}

\subsection{Latar Belakang}

Bencana tanah longsor merupakan peristiwa geologi yang terjadi karena pergerakan masa batuan atau tanah dengan berbagai tipe dan jenis seperti jatuhnya bebatuan atau gumpalan besar tanah (Faizana, 2014). Pergerakan tersebut terjadi akibat interaksi pengaruh beberapa kondisi yang meliputi geologi, morfologi, struktur geologi, hidrogeologi dan tata guna lahan (Karnawati, 2005). Faktor-faktor yang mempengaruhi terjadinya tanah longsor diantaranya adalah kemiringan lereng, tekstur tanah, permeabilitas tanah, tingkat pelapukan batuan, kedalaman efektif tanah, kerapatan torehan, kedalaman muka air tanah, dan curah hujan (Risdiyanto, 2011).

Pada musim penghujan muka air tanah akan mengalami peningkatan dan pemulihan karena proses pengisian kembali (groundwater recharged). Proses pengisian kembali air tanah dapat terjadi setiap kali terjadi hujan sehingga mengakibatkan fluktuasi tinggi muka air tanah. Curah hujan yang tinggi menyebabkan peningkatan tekanan pori air tanah sehingga mendorong naiknya muka air tanah.

Antara curah hujan dan tinggi muka air tanah menunjukkan adanya hubungan korelasi yang dapat dimodelkan secara matematis. Hasil penelitian di DAS Cileungsi hulu menunjukkan adanya korelasi linear antara curah hujan dan rata-rata kedalaman permukaan air tanah, dimana $78,47 \%$ curah hujan memberikan pengaruh kuat terhadap rata-rata kedalaman permukaan air tanah. Semakin besar hujan maka muka air tanah semakin dekat dengan permukaan tanah setempat (Hasfarila et al., 2014). Pada saat muka air tanah naik melampaui bidang gelincirnya, maka terjadi peningkatan potensi pergerakan tanah. Akibat hujan yang lebat dapat terjadi pembasahan pada tanah yang mengakibatkan berkurangnya kekuatan geser tanah karena butir-butir tanah menyerap air (Wardana, 2011). Pada kondisi tersebut dapat terjadi pergerakan tanah.

Salah satu upaya yang dapat dilakukan untuk mengatasi timbulnya korban jiwa dan kerugian harta benda dapat dilakukan dengan meningkatkan kesiapsiagaan masyarakat terhadap bencana longsor. Salah satu upaya yang dapat dilakukan berupa pemasangan peralatan untuk peringatan dini (Susilo et al., 2011). Pada tahun 2018 telah dibangun sistem peringatan dini longsor (Landslide Early Warning System/LEWS) di Kampung Jatiradio, Desa Cililin, Kecamatan Cililin, Kabupaten Bandung Barat pada tahun 2018. Dua parameter yang dipantau oleh perangkat LEWS ini adalah curah hujan dan tinggi muka air tanah. Pembangunan LEWS tersebut harus mempertimbangkan kondisi geologi setempat terutama dalam kaitannya dengan jenis tanah dan tingkat penyerapan air ke dalam tanah. Di lokasi pembangunan LEWS tersebut jenis tanahnya dipengaruhi oleh jenis batuan berupa intrusi batuan beku Gunung Gegerpulus. Tanah hasil pelapukan batuan berupa pasir lempungan (PVMBG, 2017). Berdasarkan Unified Soil Classification System (USCS), tanah jenis ini termasuk ke dalam tanah berbutir kasar dan umumnya ditulis dengan simbol SC (Sand Clay) (Kalinski, 2011). Jenis tanah mempengaruhi tingkat penyerapan air atau sifat permeabilitas tanah. Batuan beku yang secara umum tersusun atas silika akan terlapukkan menjadi mineral lempung. Tanah lempung rentan memiliki liquid limit dan indeks plastisitas yang tinggi sehingga air akan terserap bergantung pada mineral lempung dan keaktifan lempung itu sendiri (plastisitas fraksi lempung) (Woodward, 2005).

Berdasarkan hasil pemantauan pada awal musim hujan 2019 memperlihatkan kecenderungan adanya korelasi antara curah hujan dan peningkatan muka air tanah piezometrik (Prihartanto et al., 2019). Peningkatan muka air tanah akibat hujan tersebut selanjutnya akan diikuti dengan penurunan muka air tanah hingga terjadi peningkatan kembali tinggi muka air tanah karena hujan berikutnya. Kondisi fluktuasi tinggi muka air tanah tersebut dapat dimodelkan secara matematis sehingga dapat memberikan gambaran karakteristik air tanah yang spesifik di Kampung Jatiradio, Desa Cililin, Kecamatan Cililin, Kabupaten Bandung Barat. Dengan demikian pada makalah ini akan dibahas tentang model penurunan tinggi muka air tanah setiap kali setelah kejadian hujan dan hubungannya dengan curah hujan yang terjadi. 


\subsection{Maksud dan Tujuan Penelitian}

Tujuan dari penelitian ini adalah membangun model matematik penurunan tinggi muka air tanah setiap kali setelah kejadian hujan di Kampung Jatiradio, Desa Cililin, Kecamatan Cililin, Kabupaten Bandung Barat pada saat musim hujan 2019. Karakteristik penurunan tinggi muka air tersebut dapat dimodelkan secara matematis menggunakan pendekatan regresi. Model penurunan tinggi muka air tersebut dapat dihubungkan dengan pola fluktuasi curah hujan yang terjadi dengan demikian dapat diketahui hubungan antara pola curah hujan dan pola fluktuasi tinggi muka air pada periode hujan tertentu.

\section{BAHAN DAN METODE}

\subsection{Bahan}

Untuk membangun model matematika penurunan tinggi muka air tanah dan analisis hubungannya dengan curah hujan di lokasi pemasangan perangkat LEWS di Kampung Jatiradio, Desa Cililin, Kecamatan Cililin, Kabupaten Bandung Barat digunakan data hasil pengukuran curah hujan dan tinggi muka air tanah secara periodik yang diperoleh dari database perangkat LEWS selama periode 23 Februari sampai dengan 1 Maret 2019. Data curah hujan diukur menggunakan penakar hujan otomatis jenis tipping bucket sedangkan tinggi muka air tanah diukur menggunakan sensor pressure transducer. Kedua sensor tersebut diletakkan agak berjauhan pada jarak \pm 140 meter sebagaimana diperlihatkan pada Gämbar 1.

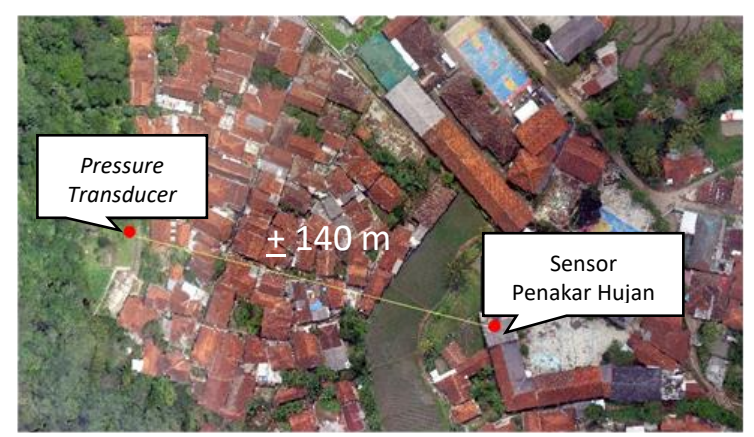

Gambar 1. Peta Lokasi dan Jarak Sensor Penakar Hujan dan Pressure Transducer

\subsection{Metode}

Pembuatan model penurunan tinggi muka air setiap kali setelah kejadian hujan di lokasi LEWS menggunakan model matematik regresi. Model ini dibangun dengan membuat grafik data tinggi muka air tanah terhadap selang waktu setiap kali terjadi kejadian hujan. Pengolahan data-data diolah dengan menggunakan perangkat lunak microsoft excel. Berdasarkan grafik tersebut dilakukan analisis regresi untuk setiap selang waktu satu kali kejadian hujan hingga sebelum terjadi kejadian hujan berikutnya. Dari kedua parameter tersebut akan dibuat grafik regresi sesuai dengan kecenderungan sebaran datanya. Berdasarkan grafik regresi tersebut dihitung koefisien determinasi sederhana $\left(R^{2}\right)$ untuk mengukur pengaruh variabel independen (waktu) terhadap variansi variabel dependen (tinggi muka air tanah).

Untuk menganalisis hubungan dan pengaruh pola fluktuasi curah hujan terhadap pola fluktuasi tinggi muka air tanah dilakukan analisis kualitatif terhadap kedua parameter tersebut. Analisis kualitatif ini dilakukan karena data tinggi muka air tanah merupakan data yang kontinu sedangkan data curah hujan tidak kontinu (sewaktu-waktu). Dengan demikian data curah hujan disandingkan bersama-sama data tinggi muka air tanah pada periode waktu yang sama untuk menggambarkan kerterhubungan antara kedua parameter tersebut. Disamping itu, karena adanya hubungan antara curah hujan, fluktuasi tinggi muka air tanah dengan kondisi geologi bawah permukaan, maka dilakukan analisis kondisi geologi yang ada di daerah pengamatan. Rentang waktu data yang digunakan untuk mengamati hubungan curah hujan dengan fluktuasi tinggi muka air tanah yaitu selama periode 23 Februari sampai dengan 1 Maret 2019.

\section{HASIL DAN PEMBAHASAN}

\subsection{Fluktuasi Curah Hujan dan Tinggi Muka Air Tanah}

Selama periode 23 Februari sampai dengan 1 Maret 2019, dari beberapa kali hujan yang terjadi, terpantau 4 kali kenaikan tinggi muka air yang signifikan yaitu pada tanggal $23,24,25$ dan 28 Februari 2019. Tinggi muka air tanah tertinggi tercapai pada tanggal 24 Februari 2019 yaitu sebesar $3.083,1 \mathrm{~mm}$ sebagaimana diperlihatkan pada Gambar 2. Pada setiap kali kejadian naik turun tinggi muka air tanah, proses peningkatan tinggi muka air tanah selalu diawali dengan intensitas curah hujan yang relatif besar. Dari grafik fluktuasi tinggi muka air tanah tampak bahwa setiap kali tercapai kenaikan tinggi maksimum muka air tanah akan diikuti oleh penurunan tinggi muka air tanah selama durasi tertentu hingga kejadian peningkatan tinggi muka air tanah selanjutnya.

\subsection{Pola Hujan dan Proses Penjenuhan Tanah}

Selama periode 23 Februari sampai dengan 1 Maret 2019 terjadi beberapa kali kejadian hujan dengan durasi yang berbeda-beda, namun hanya terdapat 3 kejadian hujan yang 
mengakibatkan peningkatan tinggi muka air tanah yang kemudian diikuti kembali oleh penurunan tinggi muka air. Peningkatan tinggi muka air tanah akibat hujan pada tanggal 28 Februari 2019 tidak dianalisis karena tidak diperolehnya data akibat terhentinya operasi LEWS pada tanggal 1 Maret 2019 pukul 12.00 WIB.

Dari grafik hubungan curah hujan dengan tinggi muka air tanah terlihat bahwa selama periode penelitian kejadian kenaikan tinggi muka air berkaitan erat dengan curah hujan yang tinggi. Durasi hujan intensitas rendah yang dapat menjenuhkan tanah berkisar antara $7-9$ jam (Tabel 1) sebelum dapat menaikkan tinggi muka air tanah dengan durasi berkisar antara 1 - 2 jam. Kenaikan tinggi muka air tanah setelah terjadi penjenuhan tanah dan hujan dengan intensitas tinggi. Selama periode tersebut awal hujan terjadi antara pukul $09.00-10.00$ WIB. Setelah tinggi muka air tanah mencapai puncak, kemudian terjadi kembali penurunan tinggi muka air tanah yang berkisar antara 20 - 70 jam saat intensitas $\mathrm{CH}$ mulai menurun. Hujan yang terjadi pada tanggal 26 dan 27 Februari tidak mengakibatkan peningkatan tinggi muka air tanah karena tidak terjadinya hujan dengan intensitas tinggi pada tanggal-tanggal tersebut.

\subsection{Model Regresi}

Data curah hujan $(\mathrm{mm} / \mathrm{jam})$ dan tinggi muka air $(\mathrm{m})$ yang diperoleh dari perangkat LEWS yang terpasang di lapangan selama periode penelitian ditampilkan dalam bentuk grafik, dimana sumbu $X$ adalah waktu (jam) dan sumbu $Y_{1}$ berupa curah hujan $(\mathrm{mm} / \mathrm{jam})$ dan variabel $Y_{2}$ berupa tinggi muka air $(m)$. Terlihat pada Gambar 2 pola fluktuasi tinggi muka air tanah dan curah hujan selama periode waktu 6,5 hari.

Dari gambar tersebut terlihat bahwa terjadi 4 kali kejadian kenaikan tinggi muka air yang diikuti oleh penurunan tinggi muka air dengan durasi tertentu. Untuk setiap kali kejadian diambil data tinggi muka air tertinggi sampai dengan terendah untuk dianalisis pola penurunananya dengan menggunakan model regresi.

Pada Gambar 3 diperlihatkan pola penurunan tinggi muka air selama periode 23 24 Februari 2019. Tinggi muka air tertinggi 2,3932 m pada tanggal 23 pukul 21.00 dan terendah $1,7057 \mathrm{~m}$ pada tanggal 24 pukul 17.00 . Persamaan regresi yang diperoleh berupa regresi linear sebagaimana diperlihatkan pada persamaan (1) dengan nilai koefisien determinasi $R^{2}=0,9631$.
$Y=-36,022 x+2339,2 \quad \ldots$ (1)

Pola penurunan tinggi muka air yang terjadi dalam periode 23-24 Februari 2019 berlangsung secara linear (Gambar 3).

Persamaan (1) menunjukkan nilai koefisien regresi sebesar 36,022 dengan konstanta 2339 ,2. Hal ini menandakan pada saat stabil atau konstan, tinggi muka air tanah pada waktu tersebut adalah $2339,2 \mathrm{~mm}$ dan setiap jam penurunan tinggi muka air tanah terjadi sebesar $36,022 \mathrm{~mm}$.

Pada periode 24 - 25 Februari 2019 tinggi muka air tertinggi terukur $3,0831 \mathrm{~m}$ pada tanggal 24 pukul 19.00 WIB dan terendah $1,8967 \mathrm{~m}$ pada tanggal 25 pukul 19.00 WIB. Persamaan regresi yang diperoleh berupa regresi linear sebagaimana diperlihatkan pada persamaan (2) dengan nilai koefisien determinasi $R^{2}=0,9988$.

$y=-49,346 x+3111,2 \quad \ldots(2)$

Dengan demikian pola penurunan tinggi muka air yang terjadi dalam periode $24-25$ Februari 2019 berlangsung secara linear (Gambar 4).

Persamaan (2) menunjukkan nilai koefisien regresi sebesar 49,346 dengan konstanta 3111,2 . Hal ini menandakan pada saat stabil atau konstan, tinggi muka air tanah pada waktu tersebut adalah $3111,2 \mathrm{~mm}$ dan setiap jam penurunan tinggi muka air tanah terjadi sebesar $49,346 \mathrm{~mm}$.

Selama periode 25 - 28 Februari 2019 hanya terjadi satu kali hujan yang mengakibatkan kenaikan tinggi muka air. Tinggi muka air tertinggi terukur 2,9487 m pada tanggal 25 pukul 20.00 WIB dan terendah $0,8524 \mathrm{~m}$ pada tanggal 28 pukul 18.00 WIB. Persamaan regresi yang diperoleh berupa regresi eksponensial sebagaimana diperlihatkan pada persamaan (3) dengan nilai koefisien determinasi $R^{2}=0,9903$.

$y=2783,6 e^{-0,017 x}$

Dengan demikian pola penurunan tinggi muka air yang terjadi dalam periode $24-25$ Februari 2019 berlangsung secara eksponensial. Bila diperhatikan secara seksama pada tanggal 27 Februari terjadi hujan dengan intensitas rendah pada pukul $10.00-13.00$ WIB yang sedikit meningkatkan tinggi muka air sehingga regresi yang diperoleh tidak linear namun cenderung eksponensial (Gambar 5). Pola eksponensial tersebut menunjukkan bahwa penurunan yang terjadi pada rentang waktu tersebut cukup cepat. 
Prihartanto, dkk: Model Penurunan Tinggi Muka Air Tanah Setelah Kejadian Hujan di Lokasi Sistem Peringatan Dini Longsor di Kampung Jatiradio, Desa Cililin, Kecamatan Cililin, Kabupaten Bandung Barat

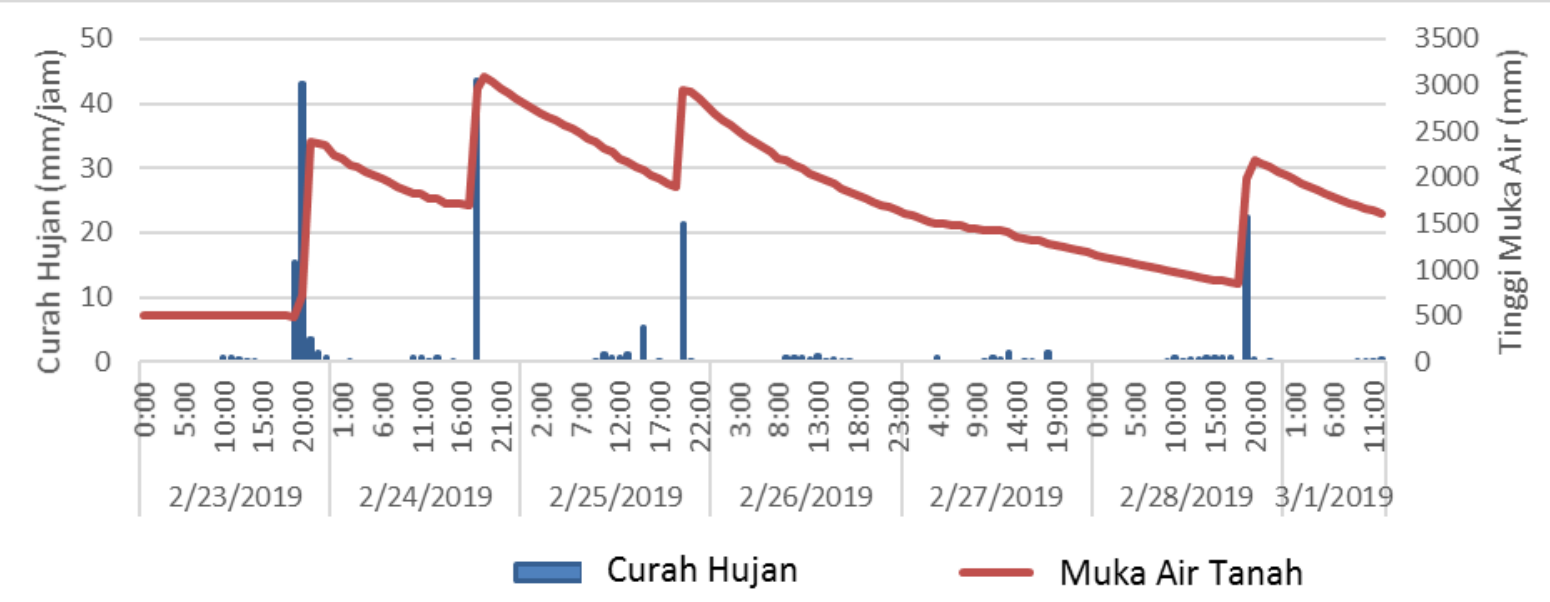

Gambar 2. Grafik Fluktuasi Curah Hujan dengan Tinggi Muka Air Tanah Setiap Jam dari Tanggal 23 Februari 2019 sampai dengan 1 Maret 2019

Tabel 1. Waktu Kejadian, Durasi Hujan dan Tinggi Muka Air Tanah

\begin{tabular}{|c|c|c|c|c|c|c|}
\hline $\begin{array}{c}\text { Waktu } \\
\text { Kejadian } \\
\text { Hujan } \\
\text { Tanggal }\end{array}$ & $\begin{array}{c}\text { Waktu } \\
\text { awal } \\
\text { kejadian } \\
\text { hujan } \\
\text { (WIB) }\end{array}$ & $\begin{array}{c}\text { Tinggi } \\
\text { Muka Air } \\
\text { Tanah } \\
\text { Maksimu } \\
\mathbf{m}(\mathbf{m})\end{array}$ & $\begin{array}{c}\text { Tinggi } \\
\text { Muka Air } \\
\text { Tanah } \\
\text { Minimum } \\
(\mathbf{m})\end{array}$ & $\begin{array}{c}\text { Durasi hujan } \\
\text { sebelum kejadian } \\
\text { kenaikan tinggi } \\
\text { muka air tanah } \\
\text { (jam) }\end{array}$ & $\begin{array}{c}\text { Waktu } \\
\text { Tercapai } \\
\text { Tinggi } \\
\text { Muka Air } \\
\text { Maksimum }\end{array}$ & $\begin{array}{c}\text { Waktu } \\
\text { Tercapai } \\
\text { Tinggi Muka } \\
\text { Air Minimum }\end{array}$ \\
\hline $23 / 02 / 2019$ & 10.00 & 2,3932 & 1,7057 & 9 & $\begin{array}{c}23 / 02 / 2019 \\
\text { Pukul 21.00 }\end{array}$ & $\begin{array}{c}24 / 02 / 2019 \\
\text { Pukul 17.00 }\end{array}$ \\
\hline $24 / 02 / 2019$ & 10.00 & 3,0831 & 1,8967 & 7 & $\begin{array}{c}24 / 02 / 2019 \\
\text { Pukul 19.00 }\end{array}$ & $\begin{array}{c}25 / 02 / 2019 \\
\text { Pukul 19.00 }\end{array}$ \\
\hline $25 / 02 / 2019$ & 9.00 & 2,9487 & 0,8524 & 9 & $\begin{array}{c}25 / 02 / 2019 \\
\text { Pukul 20.00 }\end{array}$ & $\begin{array}{c}28 / 02 / 2019 \\
\text { Pukul 18.00 }\end{array}$ \\
\hline $26 / 02 / 2019$ & 9.00 & - & - & - & Tidak & - \\
\hline $27 / 02 / 2019$ & 10.00 & - & - & - & Tidak & - \\
\hline $28 / 02 / 2019$ & 9.00 & 2,1850 & - & - & $28 / 02 / 2019$ & - \\
\hline & & & & & & \\
\hline
\end{tabular}

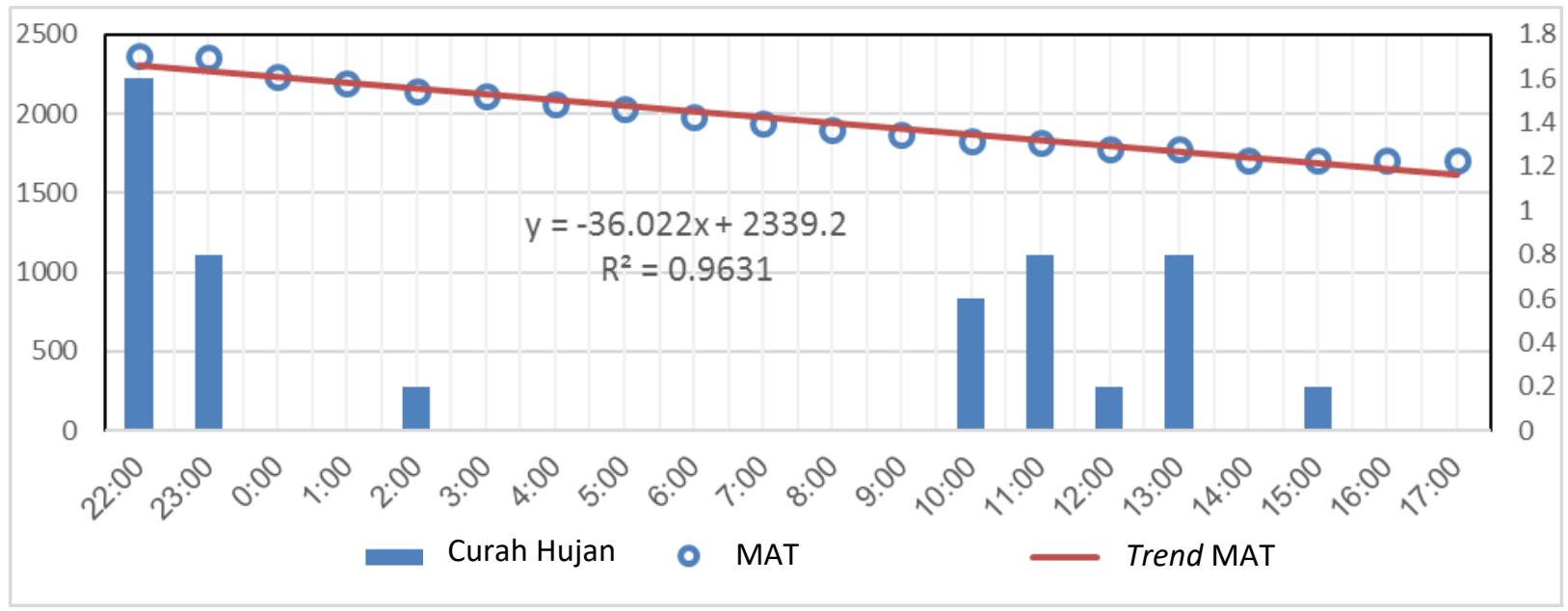

Gambar 3. Model Regresi Penurunan Tinggi Muka Air Tanah (MAT)Tanggal 23 - 24 Februari 2019 


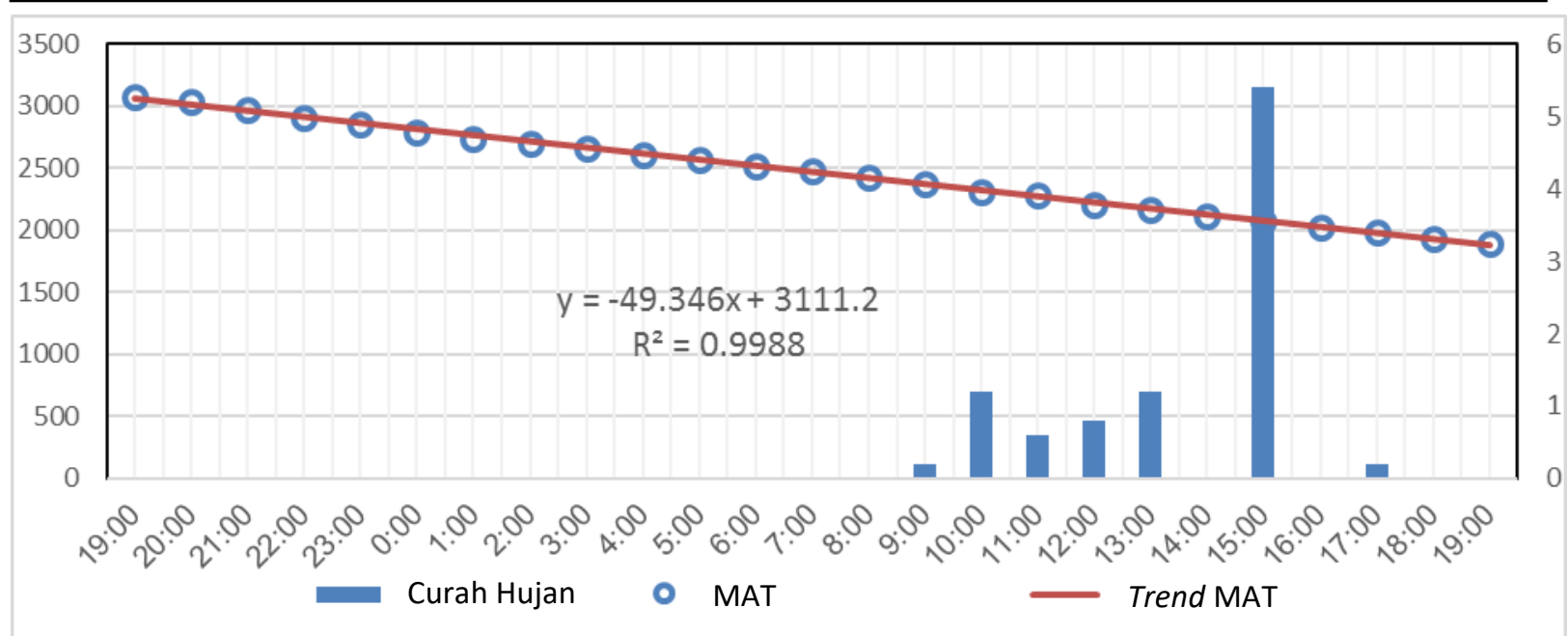

Gambar 4. Model Regresi Penurunan Tinggi Muka Air Tanah (MAT) Tanggal 24 - 25 Februari 2019

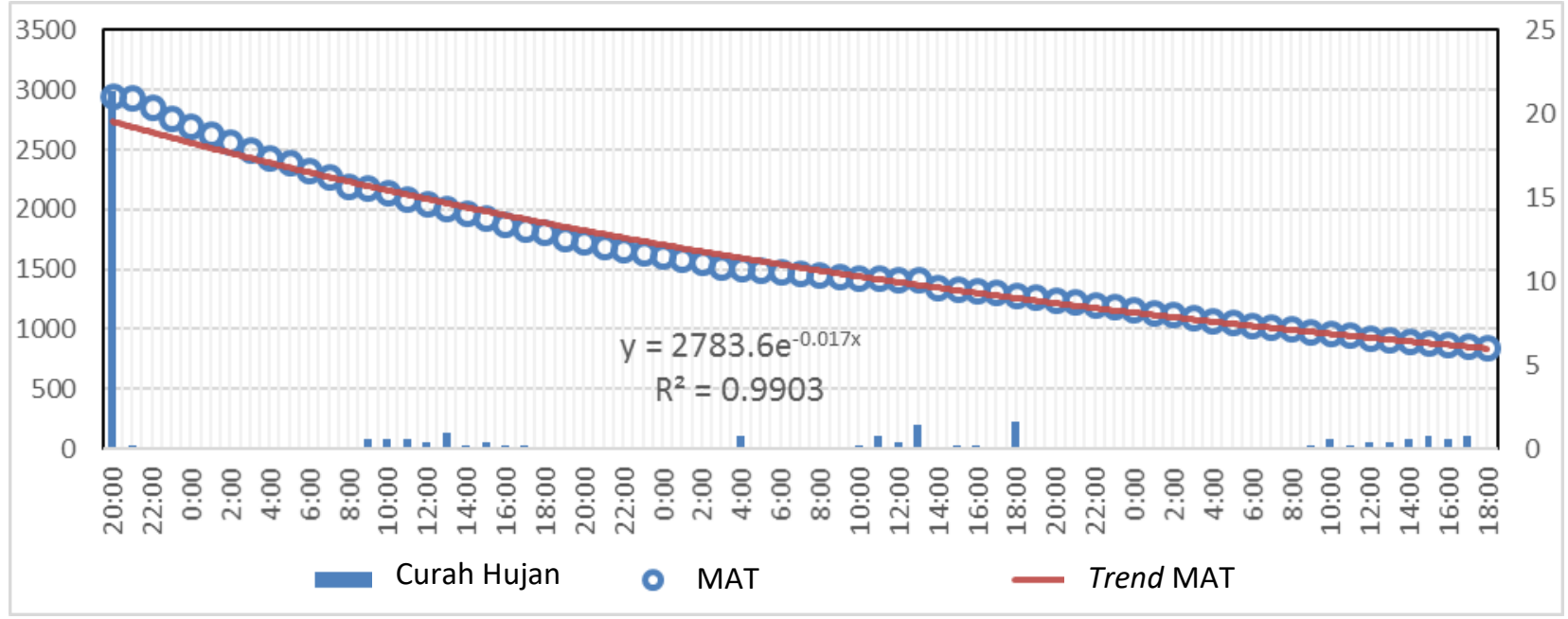

Gambar 5. Model Regresi Penurunan Tinggi Muka Air Tanah (MTA) Tanggal 25 - 28 Februari 2019

\subsection{Analisis Koefisien Determinasi}

Koefisien determinasi $\left(R^{2}\right)$ menunjukkan tingkat kebaikan model yang dihasilkan. Semakin nilai koefisien determinasi mendekati satu atau $100 \%$ maka model grafik yang dihasilkan semakin baik.

Berdasarkan persamaan grafik model trend untuk ketiga penurunan tinggi muka air tanah dihasilkan nilai koefisien determinasi sebesar 96,31\%; 99,88\%; dan 99,03\%. Ketiga nilai koefisien determinasi tersebut menunjukkan model grafik trend yang dihasilkan baik. Hal ini menunjukkan bahwa hubungan penurunan tinggi muka air tanah dengan waktu penurunanya dapat dikatakan linear untuk tanggal 23 - 24 dan 24 25 Februari 2019, serta bersifat eksponensial pada tanggal 25 - 28 Februari 2019.

Model linear yang terbentuk menunjukkan dua hingga tiga jam setelah tinggi muka air tanah meningkat, akan diikuti dengan terjadinya penurunan muka air tanah secara perlahan bila curah hujan yang terjadi lebih rendah dari sebelumnya.

Sedangkan model eksponensial terjadi karena penurunan muka air tanah yang cukup cepat. Hal ini dikarenakan, di tengah-tengah penurunan muka air tanah pada penurunan ke-2 terjadi hujan yang menjenuhkan air tanah sehingga ketinggian muka air tanah meningkat kembali dan penurunannya terjadi dalam periode waktu yang cukup lama (ditunjukkan oleh penurunan ke-3).

\subsection{Karakteristik Tinggi Muka Air Tanah}

Secara periodik, curah hujan tertinggi yang terjadi pada tanggal 23 Februari sampai 1 Maret 2019 yaitu sebesar 43,6 mm/jam yang terjadi pada tanggal 24 Februari 2019. Pada curah hujan setinggi nilai tersebut, tinggi muka air sebesar 3.083,1 mm. Waktu yang dibutuhkan untuk penurunan muka air tanah yaitu selama 24 jam. Penurunan muka air tanah tercepat terjadi 
selama 13 jam pada tanggal 25 Februari 2019 ketika curah hujan sebesar $21,4 \mathrm{~mm} / \mathrm{jam}$ dan ketinggian muka air tanah mencapai $2948,7 \mathrm{~mm}$. Penurunan yang cepat dari tinggi muka air tanah ini diperlihatkan pada model regresi non-linear yang terjadi dari tanggal $25-28$ Februari 2019 (Gambar 5).
Sedangkan waktu penurunan tinggi muka air tanah terlama terjadi selama 29 jam pada tanggal 27 Februari 2019. Pada saat tersebut curah hujan tertinggi yang terjadi yaitu 1,6 $\mathrm{mm} / \mathrm{jam}$ dengan tinggi muka air tanah sebesar $1615,5 \mathrm{~mm}$. Secara ringkas, data tersebut dapat dilihat pada Tabel 2.

Tabel 2. Data Waktu Penurunan Tinggi Muka Air Tanah (MAT) dari Tanggal 23 Februari sampai 1 Maret 2019

\begin{tabular}{c|c|c|c|c}
\hline \multicolumn{1}{c|}{ Tanggal } & $\begin{array}{c}\text { Curah Hujan } \\
\text { Tertinggi } \\
\text { (mm/Jam) }\end{array}$ & $\begin{array}{c}\text { Periode Waktu } \\
\text { Penurunan TMA } \\
\text { (jam) }\end{array}$ & $\begin{array}{c}\text { Tinggi } \\
\text { MAT } \\
\text { Tertinggi } \\
\text { (m) }\end{array}$ & $\begin{array}{c}\text { Tinggi } \\
\text { MAT } \\
\text { Terendah } \\
\text { (m) }\end{array}$ \\
\hline 23 Februari 2019 & 43,2 & 15 & 2,3932 & 0,4938 \\
\hline 24 Februari 2019 & 43,6 & 24 & 3,0831 & 1,7057 \\
\hline 25 Februari 2019 & 21,4 & 13 & 2,9487 & 1,8967 \\
\hline 26 Februari 2019 & 1,0 & 23 & 2,7013 & 1,6416 \\
\hline 27 Februari 2019 & 1,6 & 29 & 1,6155 & 1,1853 \\
\hline 28 Februari 2019 & 22,4 & 16 & 2,1850 & 0,8524 \\
\hline 01 Maret 2019 & 0,4 & - & 2,0197 & 1,6062 \\
\hline
\end{tabular}

Hal tersebut menunjukkan bahwa tinggi muka air tanah dipengaruhi oleh akumulasi curah hujan yang terjadi dan seberapa sering hujan itu terjadi dengan intensitas tertentu. Akumulasi curah hujan dengan intensitas yang cukup sering mengakibatkan tinggi muka air tanah meningkat dan waktu penurunan muka air tanah tersebut semakin lama. Penurunan muka air tanah bergantung kepada laju infiltrasi.

Diketahui bahwa informasi mengenai infiltrasi penting untuk memprediksi tinggi muka air tanah karena jika suatu daerah terdiri atas material pasir dengan permeabilitas tinggi serta tidak terdapat lapisan kedap air diatasnya, maka limpasan permukaannya (run-off) akan kecil. Sebaliknya, bila terdiri dari material berlempung yang kedap air maka limpasan permukaannya besar.

Air hujan yang jatuh di permukaan tanah akan berubah menjadi aliran air di bawah permukaan (sub surface flow). Aliran air ini yang mempengaruhi tinggi muka air, dan meresap di antara pori-pori tanah menyebabkan tanah menjadi jenuh (saturated). Tanah yang jenuh mengurangi nilai kohesi dan kekuatan tanah untuk menopang akan semakin kecil sehingga menyebabkan terjadinya longsor.
Kampung Jatiradio, Kecamatan Cililin, Kabupaten Bandung Barat merupakan suatu daerah dengan topografi perbukitan dan kondisi material tanah yang cukup beragam. Hasil pengamatan menunjukkan bahwa pada lokasi sensor pressure transducer ditemukan singkapan dengan material tanah berukuran partikel lempung-lanau.

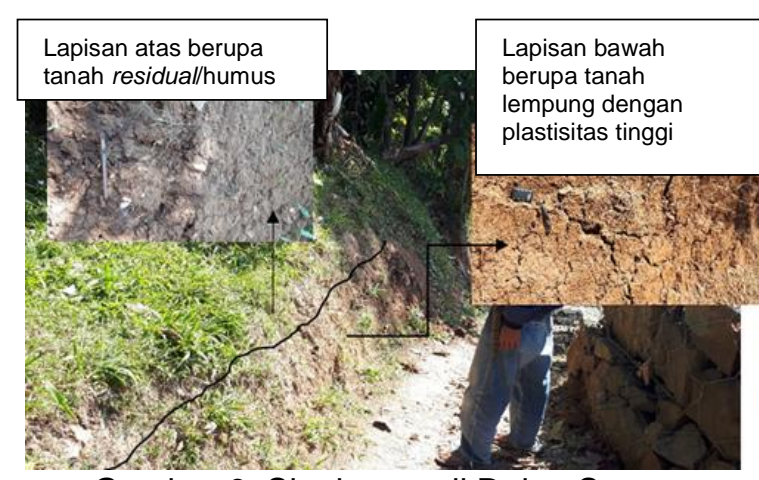

Gambar 6. Singkapan di Dekat Sensor

Pressure Transducer dengan Material Lempung

Singkapan yang diamati memiliki panjang 2,4 $\mathrm{m}$ dengan tinggi singkapan $1 \mathrm{~m}$. Material pada bagian atas merupakan tanah residual 
atau tanah humus, dengan warna cokelat keabuan, struktur perlapisan humus/berserat, kondisi sangat lepas, dan tersementasi buruk. Lapisan ini merupakan tanah residual dengan proses pelapukan yang sangat intensif.

Pada bagian bawah singkapan adalah tanah dengan material lempung, bersifat kohesif, berwarna cokelat, struktur perlapisan homogen, kondisi lepas dan tersementasi buruk. Lapisan ini memiliki tingkat plastisitas tinggi dengan kehadiran mineral lempung.

Setelah diamati, dapat diketahui bahwa tinggi muka air tanah yang diamati pada grafik hubungan curah hujan dengan tinggi muka air tanah terbilang cukup lambat dikarenakan material yang berada pada lokasi tersebut memiliki permeabilitas yang cukup rendah yaitu lempung. Karakteristik material lempung yang memiliki tekstur butiran dengan ukuran kurang dari 0,004 $\mathrm{mm}$ menyebabkan laju infiltrasi yang terjadi sangat lamban. Sehingga waktu air hujan dipermukaan untuk meresap kedalam tanah juga cukup lama.

\section{KESIMPULAN}

Model matematika regresi penurunan tinggi muka air tanah periode 23 Februari sampai dengan 1 Maret 2019 di sekitar lokasi pemasangan LEWS di Kampung Jatiradio, Desa Cililin, Kecamatan Cililin, Kabupaten Bandung Barat menunjukkan pola penurunan tinggi muka air tanah yang linear. Namun, apabila saat terjadi penurunan muka air tanah yang diselingi dengan kejadian hujan dengan intensitas tidak terlalu besar, akan terjadi kenaikan dan penurunan muka air tanah kembali yang terjadi secara cepat sehingga pola hubungan kedua variabel tersebut bersifat eksponensial. Model penurunan muka air tanah dengan curah hujan ini dipengaruhi oleh jenis tanah di Jatiradio yang bersifat lempung-lanau yang menyebabkan laju infiltrasi air lambat.

\section{PERSANTUNAN}

Ucapan terima kasih kami sampaikan kepada Kepala Badan Penanggulangan Bencana Daerah (BPBD) Kabupaten Bandung Barat, Camat Cililin, Kepala Desa Cililin, Bapak Hamzah Eksa Sukma Kepala Dusun Jati Radio. Penelitian ini merupakan bagian dari kerjasama penelitian antara PTRRB-BPPT, dan Badan Penanggulangan Bencana Daerah (BPBD) Kabupaten Bandung Barat pada tahun 2016 sampai dengan 2019.

\section{DAFTAR PUSTAKA}

Faizana, F. 2014. Pemetaan Risiko Bencana Tanah Longsor Kota Semarang, Prodi Teknik Geodesi, Fakultas Teknik Universitas Diponegoro.

Hasfarila, H., E. Kusratmoko \&, Supriatna. 2014. Perubahan Fluktuasi Permukaan Air Tanah di Daerah Aliran Cileungsi Hulu Jawa Barat, Departemen Geografi, FMIPA UI.

Kalinski, M.E. 2011. Soil Mechanics Lab Manual, Second Edition. United State: John Wiley \& Sons, Inc. p 53.

Karnawati, D. 2005. Bencana Alam Gerakan Massa Tanah di Indonesia dan Upaya Penanggulanggannya. Penerbit Fakultas Teknik Geologi UGM. 232hal.

Prihartanto. 2019. Pembangunan Sistem Peringatan Dini Bencana Longsor Di Kampung Jatiradio, Desa Cililin, Kabupaten Bandung Barat, Provinsi Jawa Barat, Jurnal Alami, Jurnal Teknologi Reduksi Risiko Bencana, BPPT, 3(2): 8087.

PVMBG. 2017. Laporan Singkat Pemeriksaan Gerakan Tanah di Desa Cililin, Kecamatan Cililin, Kabupaten Bandung Barat, Provinsi Jawa Barat. [terhubung berkala]. https://vsi.esdm.go.id/index.php/gerakantanah/kejadian-gerakan-tanah/1504laporan-singkat pemeriksaan-gerakantanah-di-desa-cililin-kecamatan-cililinkabupaten-bandung-barat-provinsi-jawabarat [14 Februari 2019].

Risdiyanto, I. 2011. Identifikasi Daerah Rawan Longsor. Institut Pertanian Bogor, 10.13140/RG.2.1.4316.5684.

Susilo, A., D.R. Santoso, A. Rachmansyah, \& Y. Zaika. 2011. Desain Sistem Peringatan Dini Zona Rawan Longsor dengan Penerapan Sensor Kelembaban dan Getaran pada Tanah. Jurnal Meteorologi dan Geosifika, BMKG, 12(3): 283-289.

Wardana, I.G.N. 2011. Pengaruh perubahan Muka Air Tanah dan Terasering terhadap Perubahan Kestabilan Lereng, Jurnal IImiah Teknik Sipil (JITS), 15(1): 83-92.

Woodward, J. 2005. An Introduction to Geotechnical Processes. London \& New York: Spon Press. 307p. 